\title{
Charcot like changes in Leprosy
}

\author{
HIDEO MATSUDA \\ Department of Orthopedic Surgery, Kumamoto University School of Medicine
}

(Chairman: Prof. Tatsuji Tamai)

Charcot-like changes in leprosy patient are mostly observed on foot and ankle, but rarely on other joints.

It was clinically observed that of 38 cases, 3 cases had the destruction of the whole tarsal bones, 19 cases on ankle, 4 cases on subtalar joints, 8 cases on Chopart's joint and 4 cases on Lisfranc's joint.

Charcot-like changes of ankle may be caused by repeated sprain. Clinical finding shows swelling, lateral instability and pes varus deformity of ankle.

The sclerosis, deformity of the tarsal bones and loose bodies in ankle are roentogenologically noted.

Proliferating bone changes are rare and the arthicular surface of the tibia is not damaged.

In Chopart's and subtalar joints, the condition begins with warmness and swelling without any cause.

The stability of the foot is kept well, though roentogenogram shows the destruction of navicular bone and calcaneum.

In Lisfranc's joint, the destruction of cuboid bone, caused by sprain, occurs, but may result in only pes valgus and planus deformity and stability of foot is kept well. 


\title{
“らい”の Charcot 様関節変化
}

\author{
松田秀 雄 \\ 熊本大学医学部整形外科学教室 (主任 : 玉井達二教授)
}

（受付1969年 7 月 25 日）

\section{いとぐち}

“らい”は末梢の皮膚と神経を侵す疾患である。“ら い”の足では, 皮膚は stocking anaesthesia の状態で, 中枢に行くに従い，皮膚は侵されていない。末梢神経麻 㾝は下肢では腓骨神経麻㾇による drop foot と, 後脛 骨神経麻疩のための claw toe とになりやすい。この anaesthetic foot と, drop foot 及び claw toe の変形 は，容易に足穿孔症をつくり，二次感染のために骨は破 壊吸収されいろいろな奇怪なレ線像を示す。この破壊吸 収は足根骨迄に及ぶことはまれである。

足根骨の破壊は Charcot's joint としてみられ，多く の成書の中にも, 神経病性関節症を起す疾患の中にかな らず“らい”はあげられている。しかし“らい”の Charcot's joint の報告は少なく, Tabes dorsalis や Diabetes がほとんどで，その中に $1 ， 2$ 例の症例を加えて あるに過ぎない。“らい”の Charcot’s joint の報告 は，1961年 Paterson ${ }^{11}$ が Talus and Navicular Neuropathy の19例を数え，“らい”患者の $2 \%$ ほどに発生す るとのべている。1969年 Harris と Brand ${ }^{22}$ は Anaesthetic foot の足根骨の破壊の pattern を5つに分類 し，詳細に記載している。その破壊の基礎になるものは 痛覚の脱出と旺盛な活動性にあり, 他の重要な因子とし ては，sepsis，筋麻疩及び外傷であるとしている。Charcot's joint の説明の中に sepsis がはいってくると， 椂相を複雑にするのであるが，Charcot's joint という 言葉は使用せず, Disintegration of the Tarsus といっ ていて, この $5 つ の$ pattern の中に sepsis から起る 2 つの type のものを入れている。

“らい”の Charcot's joint は Tabes dorsalis や Diabetes に見られるものとよく似てはいる。しかし， 増殖性変化がなく，破壊が主であること，その破壊も他 にくらべて無軌道でないこと，足部の関節にだけ多くみ られて，他の関節には見られないことなどが，異ってい る。足部の関節の中でも，足関節と，その他の Chopart 関節などとは, 起り方, 臨床所見並びにレ線像も違って
いる。そこで，これら“らい”の足根骨にみられる変化 を “Charcot 様” 関節变化と名ゔけて，いままで経験 した事柄を述べたい。

\section{調查対象}

国立療養所菊池恵楓園患者が対象であり, 昭和 42 年 9 月一斉検診をした 1277 名より, 足部の腫脹, 変形などが あった 157名をえらび出し，その中107名，118足につい てレ線撮影をした所，11例の Charcot 様変化を認めた。 その内訳は, 足根骨全体の破壊 1 例, 足関節 3 例, 距骨 下関節 2 例, Chopart 関節 3 例, Lisfranc 関節 2 例で あつた。この11例に，これまで集めえた27例を加え，計 38例について検討を加える。

\section{成 績}

これら Charcot 様変化をよく検討すると，おのおの の関節を中心として変化が起ってきているので, 各関節 毎に分類して述べる。Table 1 のように，足根骨全体が 破壊されているむの 3 例, 足関節を中心として変化のあ るもの19例, 距骨下関節 4 例, Chopart 関節 8 例, Lisfranc 関節 4 例であった。

Table 1 Charcot like changes

\begin{tabular}{l|rc}
\hline all tarsus & 3 & cases \\
ankle & 19 & $\prime \prime$ \\
subtalar & 4 & $\prime \prime$ \\
Chopart & 8 & $\prime \prime$ \\
Lisfranc & 4 & $\prime \prime$ \\
\hline total & 38 & cases \\
\hline
\end{tabular}

1. 足根骨全体

足根骨全体の破壊を有するもの 3 例を Table 2 に示 す。これらはレ線上，足根骨がほとんど 全部破壊され ているもので，どこの関節が主として破壊されているか 判然としないものである。これらの臨床上の特長をひろ ってみるに, 腫脹は皆高度で, 変形も著しく，2 例は内 
反が強く, 1 例は前足部の外反変形と後足部の内反が強 い。安定性は全例とも lateral stability が悪く, 1 例は 動摇関節を呈して, 装具なして捗行はできない。この ように腫脹, 変形, 異常可動性, 安定性不良といった Charcot's joint の臨床上の特長を, 皆もっていて, レ 線上の破壞も著しく, どこがどうなっているか判然とし ない程, 位置関係もわからない。(Fig. 1) しかし足関 節の脛骨関節面の破壊は見られない。関節面は硬化像を 示しているが, その形をはっきりとどめている。このこ とは Tabes dorsalis や Diabetes と, はっきり違う点 であると思われる。これは足関節の脱臼, 骨折というよ うな大きな外傷にもとづくものではないことを示してい る。 3 例とも 15年〜20年前に捻挫をしたが，治療をうけ ず,その後から度々捻挫をくり返すようになって, stability を悪くしていったといっている事実からも明らか である。いずれも捻挫の治療は受けておらず，捻挫のく り返しによって生じたものであろうことがらかがわれ る。もちろん感染は 1 度も経過中に遭遇していない。

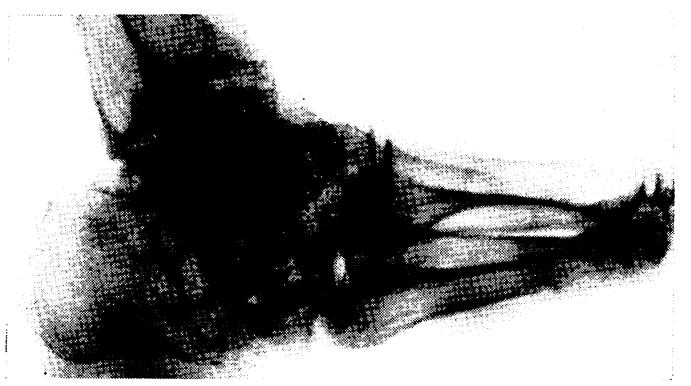

Fig. 1 Charcot-like changes in tarsal bones.

症例 1, 61歳古, L型, らい発病経過44年, 15年前に 捻挫をして, 前足部の外反変形をみている。その後, 足 部が不安定の状態になり捻挫をしていたが，昭和38年11 月からは捻挫のくり返しがひどくなっている。その時の レ線像では Fig. 2 に示すように Lisfranc 関節の破壊 変形はあるが, 硬化像を示していて, 前足部の stability はよい。そして足関節には，まだ変化は起ってきていな い。昭和 39 年 6 月, 7 力月後のレ線像では, 足関節の変

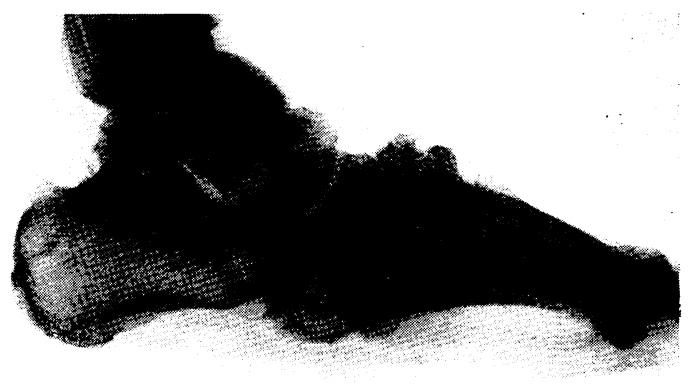

Case 1 Radiographs showing progressive disintegration of tarsal bones caused by repeated sprain.

Fig. 2 Radiograph in November, 1963 shows disintegration of the Lisfranc's joint.

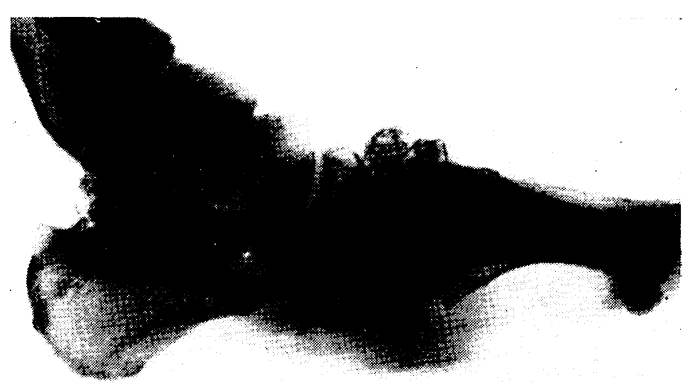

Fig. 3 Roentogenogram of June, 1964; Charcotlike changes developed in the ankle.

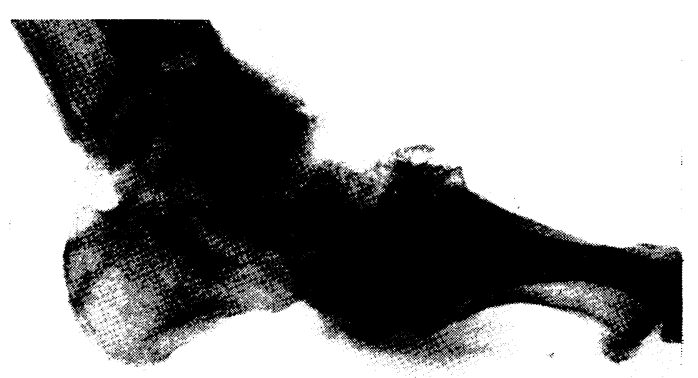

Fig. 4 March, 1967. Charcot-like changes were noted to have extended to the whole tarsal bones.

Table 2 All tarrus

\begin{tabular}{|c|c|c|c|c|c|c|c|c|c|c|c|c|}
\hline No. & name & sex & age & type & $\begin{array}{l}\text { drop } \\
\text { foot }\end{array}$ & cause & $\begin{array}{c}\text { tearm } \\
\text { since onset } \\
\text { (years) }\end{array}$ & swelling & deformity & stability & $\begin{array}{l}\text { abnormal } \\
\text { mobility }\end{array}$ & pain \\
\hline 1 & K.O. & $\mathrm{F}$ & 61 & $\mathrm{~L}$ & + & $\begin{array}{l}\text { repeated } \\
\text { sprain }\end{array}$ & 15 & H & varus & bad & H & - \\
\hline 2 & N.O. & $\mathrm{F}$ & 72 & $\mathrm{~T}$ & + & $\prime \prime$ & 20 & H & valgus & poor & H & - \\
\hline 3 & K.T. & $\mathrm{F}$ & 51 & $\mathrm{~L}$ & - & $\prime \prime$ & 20 & $H$ & varus & poor & $H$ & $\div$ \\
\hline
\end{tabular}


化が少し現われてきている。すなわち距骨が変形し, 硬 化像が增し，距骨下関節では破壊を生じ，不規則になっ ている (Fig. 3 ) 43年 3 月， 4 年後のレ線像は一段とそ の変化が進んでいる。距骨, 踵骨, 舟状骨の各関節面の 破壊が著しく, 距骨を中心として磨滅されたような破壊 像が見られる。(Fig. 4 ) この一連のレ線写真で, 4 年 間の変化の過程がよくわかる。これは長い閒かかって, 足根骨が破壊されたことを示し，ある1つの大きな Trauma が関係している像とは考えられない。故にこれ ら足根骨全体の破壊を示寸 Charcot 様関節は, 何らか の基礎的変化を基盤として, 捻挫のくり返しによって, 起ったものと推定される。

\section{2. 足関節}

足関節にみられる Charcot 様変化は“らい”におい ては特哄な点がいくつかみられる。この特異な点に注目

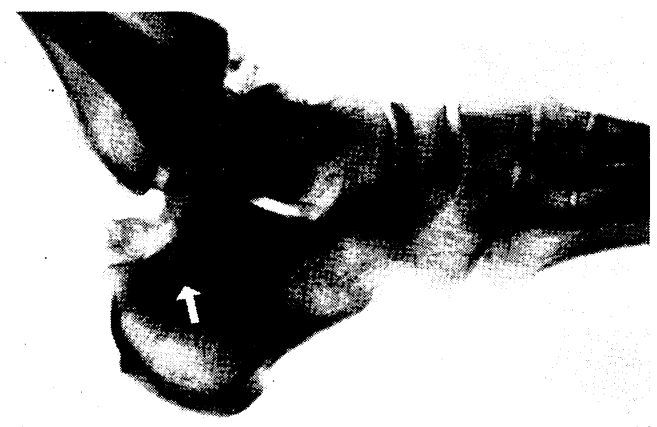

Fig. 5 Charcot-like changes in the ankle.
して見ると $2 つ の$ 型に分けることができる。

a）まず第 1 に足関節の捻挫をくり返す中にあって, 前者のように足根骨全体の破壊を有するまでにはいた。 てないが，Fig. 5 に示すように距骨の破壊変形と硬化が みられ, 足関節の周囲には大小の遊離体がみられる一連 の変化を有する型がある。

このようなレ線上の変化を有するものは Table 3 に 示すように13例ある。これらは距骨を中心として起って きている変化とみてよいと考える。この距骨の変形と硬 化と遊離体は足関節の不安定による関節障害のために起 った変化とみてよいと思う。すなわち, この不安定性は 捻挫が誘因となって起り，その不安定性のために捻挫を くり返すことにより, 関節障害をきたし, この様な変化 をきたしたものと思われる。これらの臨床上の特長は lateral instability によって内反変形をしていることで ある。腫脹は中程度に存在するのが常で, 腫脹が高度の ものは現在捻挫をくり返しているものである。つまり， 足関節捻挫は関節包及び鞋帯の断裂と, 関節血腫をつく るが, 疼痛はないか, あっても軽度のため, 彼らはその 揄挫を軽視して歩き続ける。その当然の結果として関節 包は弛緩したままの状態になり， stability は悪くなり， 内反変形をきたし, 捻挫をくり返すことにより, 関節変 化が強くなって行くものと思われる。

一方腫脹の軽度のものが，これらの中にあるが，それ らは現在捻挫をくり返さず，経過しているものである。 これら腫脹軽度のものは, stability は比較的よく保た

Table 3 Ankle joint (No. 1)

\begin{tabular}{|c|c|c|c|c|c|c|c|c|c|c|c|c|c|}
\hline No. & Name & $\operatorname{sex}$ & age & type & $\begin{array}{l}\text { drop } \\
\text { foot }\end{array}$ & cause & $\begin{array}{c}\text { tearm } \\
\text { since onset } \\
\text { (years) }\end{array}$ & $\begin{array}{l}\text { treatment } \\
\text { at onset }\end{array}$ & swelling & deformity & stability & $\begin{array}{c}\text { abnormal } \\
\text { mobility }\end{array}$ & pain \\
\hline 1 & Y.M. & $\mathrm{F}$ & 42 & $\mathrm{~L}$ & - & $\begin{array}{l}\text { repeated } \\
\text { sprain }\end{array}$ & 2 & none & H & varus & poor & H & + \\
\hline 2 & K. K. & $\mathrm{M}$ & 40 & $\mathrm{~L}$ & + & tumble & 4 & plaster cast & $H$ & $\prime \prime$ & $\prime \prime$ & H & + \\
\hline 3 & M. T. & $\mathrm{F}$ & 46 & $\mathrm{~T}$ & + & $\begin{array}{l}\text { repeated } \\
\text { sprain }\end{array}$ & 0.5 & none & Ht & "I & 11 & H & - \\
\hline 4 & E.K. & $E$ & 53 & $\mathrm{~T}$ & + & $\prime \prime$ & 9 & $\prime \prime$ & H & $\prime \prime$ & "I & H & + \\
\hline 5 & O.K. & $F$ & 57 & $\mathrm{~L}$ & + & "I & 6 & $\prime \prime$ & tt & $\prime \prime$ & $\prime \prime$ & H & + \\
\hline 6 & J.O. & Mi & 42 & $\mathrm{~L}$ & + & $\prime \prime$ & 7 & $\prime \prime$ & H & $\prime \prime$ & $\prime \prime$ & $H$ & - \\
\hline 7 & T.M. & $\mathrm{F}$ & 28 & $\mathrm{~T}$ & + & 'I & 10 & '" & + & 'l & "I & H & - \\
\hline 8 & J.Y. & $\mathrm{M}$ & 45 & $\mathrm{~L}$ & + & sprain & 8 & plaster cast & $H$ & $\prime \prime$ & good & - & - \\
\hline 9 & T.U. & $\mathrm{M}$ & 37 & $\mathrm{~L}$ & + & fall & 8 & $\prime \prime$ & + & "I & $\prime \prime$ & - & + \\
\hline 10 & T.W. & Mi & 42 & $\mathrm{~L}$ & - & sprain & 6 & $\prime \prime$ & +- & "I & $\prime \prime$ & - & - \\
\hline 11 & T.Y. & $\mathrm{M}$ & 54 & $\mathrm{~L}$ & + & $\prime \prime$ & 5 & $\prime \prime$ & + & "I & fair & - & - \\
\hline 12 & T.F. & MI & 57 & $\mathrm{~L}$ & + & $\prime \prime$ & 8 & $\prime \prime$ & $\cdot t$ & "I & good & - & - \\
\hline 13 & H. T. & $\mathrm{M}$ & 50 & $\mathrm{~L}$ & + & 'I & 2 & "I & + & $\prime \prime$ & 'I & - & + \\
\hline
\end{tabular}


れ, 従ってレ線所見も距骨の変形の変化は強くても, 他 に比較すれば, 著しくなく, 遊離体の数も少なく, 大小 不同なども少なくレ線像は全体として安定した感じをう ける。(Fig. 6) これらは, 皆捻挫の初期にギプス固定 治療した群である。このことは大切な事で, 初期の捻挫 を軽視せず，治療を十分に行なっていると，このような Charcot 様変化は起こらないか，または起っても軽度 で, stability は比較的よく保たれて, 破壊は進行しない ことを意味すると思う。Table 3 の症例 8 から13迄の 6 例が，このグループにはいり，同じレ線変化を示してい るが，腫脹は少なく，異常可動性もなく，従って stability もよく疼痛をみるのも少なくなっている。このこ とは初期治療の結果だと考えている。

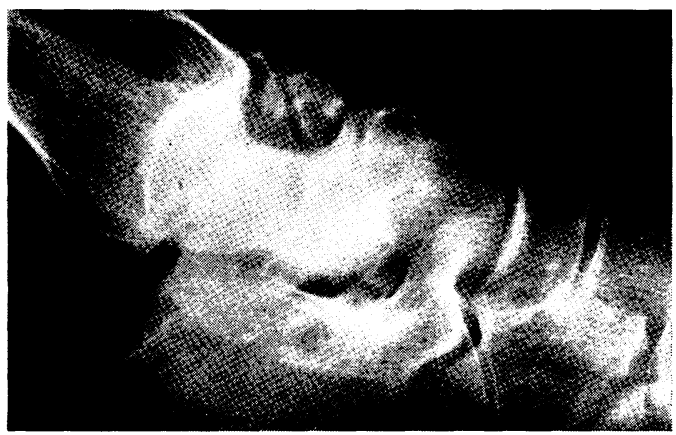

Fig. 6 Case with his ankle immobilized in plaster cast at the onset of sprain.

症例 2, 42歳古, L型, “らい” 発病経過 24 年昭和 40 年 8 月，左足関節を捻挫し，その時は治療することなく 治漓していた。昭和 42 年 2 月に再び左足関節を捻挫して より, 同月に $2 \sim 3$ 回捻挫をし, 昭和 42 年 6 月からは捻 挫のくり返しがはげしくなり，腫脹も高度となったの で，外来を訪づれた。左足関節は腫脹高度で， lateral stability が悪く，起立位で内反位をとり，上線所見は 距骨は変形し，硬化が著しく，踵骨の後方関節面下にも 破壊が及び，硬化像を示している。足関節には大小の遊 離体を認める。(Fig. 7 ) ギプス固定 2 力月後, 固定免荷 装具をつけて観察したが，8力月後にもレ線像に改善な く，破壊は少し進行した像を示したので，足関節固定術 を昭和 43 年 2 月 5 日に施行した。

足関節には多量の 関節液が認められ，関節包は肥厚 し, 絨毛増殖し, 大小多数の遊離体を認めた。足関節面 の軟骨は粗造で, ところどころ Erosion を示し, 距骨 は硬化像が示すように，骨自体は硬く感じられた。軟骨 は切除し，腓骨を Chip にして，骨移植をし，K-U

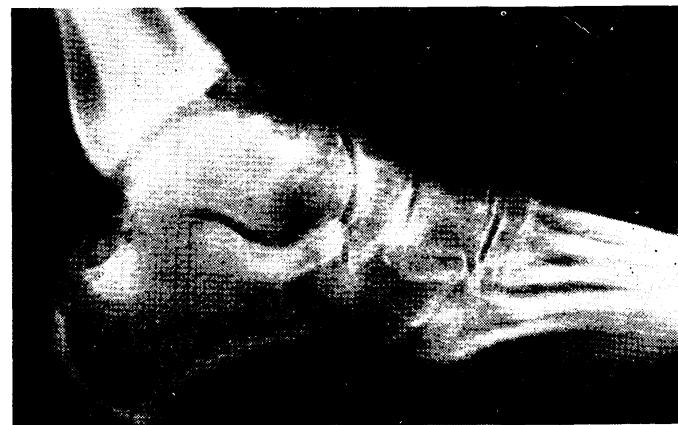

Case 2 Has suffered from remarkable swelling of her ankle and pes varus deformity caused by repeated sprain since February, 1967.

The arthrodesis of the ankle were performed in February, 1968, because the pes varus deformity had not been corrected with both plaster cast of two month's duration and brace applied.

Fig. 7 Patient received the arthrodesis of her ankle in February, 1968.

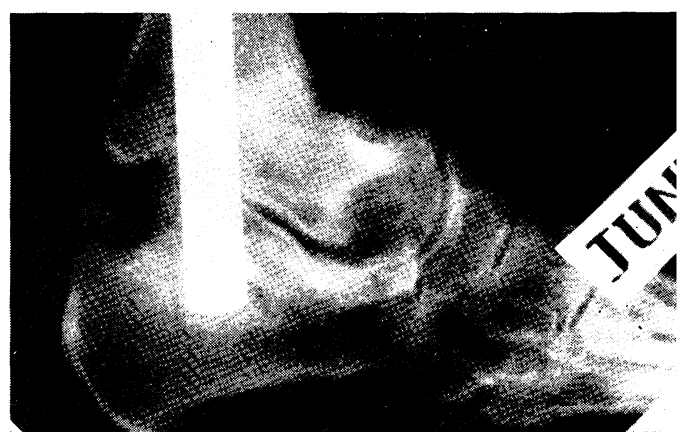

Fig. 8 Four months after operation with the use of K-U-compression plate.

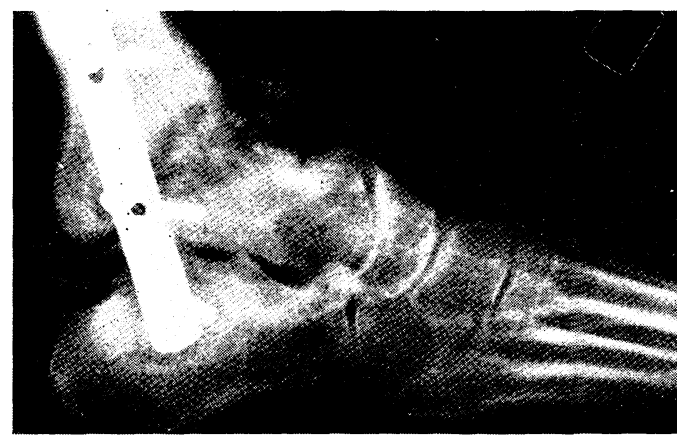

Fig. 9 Eight months later, spontaneous swollen ankle was noted and the arthrodesis had ended in failure. 
Compression plate にて, 内固定を施した。 4 力月後に は，骨癒合は完成されたかに見えたが，8力月後誘因な く腫脹し, 腫脹は下腿全体に及び, レ線像では破壊が進 行し，固定術は失敗に終っている。Charcot 関節と同様 Charcot 様関節の固定術の困難性を物語る 1 例である。

(Fig. 8, 9)

手術時に採取した䋐毛は慢性炎症像を示しその中には Leproma の存在は認められず, dead bone も認められ なかった。また遊離体の中にも Leproma は認められな かつた。

b）第 2 に足関節内外踝が突出している変形の型があ り，これらのレ線像は距骨の変形が著しく，脛骨の足関 節面下の硬化と不規則があり，足関節内で脛骨前面に Fragment を有するものが多い。(Fig. 10)

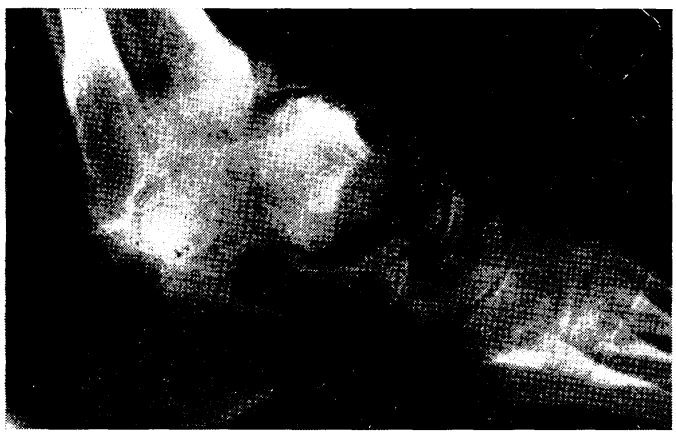

Fig. 10 Case with Charcot-like changes of his ankle, which might be due to dislocation-fracture.
これらのレ線像は翂形性関節症と名づけられるのかも 知れないが，レ線上はその程度が高度で，関節腔の狭 少もなく，関節辺縁の骨隆起といったものがみられない 点, 変形性関節症とは区別さるべきものと考え, これら もCharcot 様変化とした。この群に属する症例は 6 例 あり, Tabel 4 に示す。

いずれも足関節内外踝が突出してはいるが， stability は比較的よく保たれ，歩行能力は案外良好である。しか し長く歩くと疼痛を訴えるものが多かった。これらの症 例の全例に捻挫の既往歷はあるが，捻挫のくり返しはな く，捻挫後よりすぐに足関節内外踝突出の変形をみてい るので，この捻挫の時に足関節脱臼骨折があったのでは ないかと思われる。この足関節内骨折後疼痛が少ないた めに，無治療のまま歩き続けて，このような変形性変化 がひどくなったものと思われる。また足関節には全然疼 痛がない状態ではなく，前述のように，少しの痛みがあ るために，荷重を自制するためか Tabes dorsalis や Diabetes に見られる無軌道の破壊と増殖とはならず, このような型をとったものと考えられる。事笑“らい” では脛骨が破壊された症例は全例を通じてみあたらない のは，その部に疼痛があるためではないかと思われる。 この事については Harris と Brand は次の様に説明し ている。「距骨上表面と足関節が損傷をうけることは “らい”ではまれであることは興味深い。これに対して Tabes では足関節がやられるのは比較的普通にみられる ところである。これは足関節が“らい”で通常侵かされ る脛骨神経のところよりさらに上部から起ってきた脛骨

Table 4 Ankle joint (No. 2)

\begin{tabular}{|c|c|c|c|c|c|c|c|c|c|c|c|c|c|}
\hline No. & Name & $\operatorname{sex}$ & age & ype & drop & cause & $\begin{array}{c}\text { tearm } \\
\text { since onset } \\
\text { (years) }\end{array}$ & $\begin{array}{l}\text { treatment } \\
\text { at onset }\end{array}$ & swelling & deformity & stability & $\begin{array}{l}\text { abnormal } \\
\text { mobility }\end{array}$ & pain \\
\hline 1 & M.M. & M & 49 & $\mathrm{~L}$ & - & sprain & 6 & none & + & $\begin{array}{l}\text { projection } \\
\text { of both } \\
\text { malleoren } \\
\text { with valgus }\end{array}$ & good & - & + \\
\hline 2 & J.M. & M & 40 & $\mathrm{~L}$ & + & fall & 6 & none & + & $\begin{array}{l}\text { projection } \\
\text { of both } \\
\text { malleoren }\end{array}$ & good & - & + \\
\hline 3 & T.M. & M & 39 & $\mathrm{~L}$ & + & sprain & 10 & none & + & $\prime \prime$ & good & - & + \\
\hline 4 & T.A. & $\mathrm{F}$ & 39 & $\mathrm{~T}$ & + & sprain & 3 & none & + & $\begin{array}{l}\text { projection } \\
\text { of both } \\
\text { malleoren } \\
\text { with varus }\end{array}$ & poor & + & + \\
\hline 5 & T. K. & $\mathrm{F}$ & 37 & $\mathrm{~L}$ & + & sprain & 15 & none & $H$ & varus & poor & + & + \\
\hline 6 & G.M. & M & 42 & $\mathrm{~L}$ & + & sprain & 3 & none & + & $\begin{array}{l}\text { projection } \\
\text { of both } \\
\text { malleoren }\end{array}$ & good & - & + \\
\hline
\end{tabular}


神経の一部の神経支配をうけているためである」として いる。

“らい”において脛骨神経が侵かされるところは，通 常後脛骨神経で，足関節直上のところであり，このため に Claw toe の変形をみる。脛骨神経が侵かされて, 足関節の底屈ができないものは著者が調べた菊池恵楓園 患者の下垂足の中では14\%に過ぎない。また手術時に， しばしば足関節の深部の知覚が残っていることを経験し ているように，上位で脛骨神経が侵かされることは少な いので，足関節の脛骨面は破壊が及ばないものと思われ る。

症例 $3 ， 49$ 歳今，L型，らい発病経過33年， 6 年前に 左足関節を捻挫し，腫脹はあったが治療することなく放 置, 腫脹が消腿してからは，足関節内外踝が突出した変 形を示し, Pes valgus となった。 stability は比較的良 好なために，そのまま歩行し続けている。異常可動性が 軽度にみられ，運動時には雑音が聞かれ，長く歩くと疼

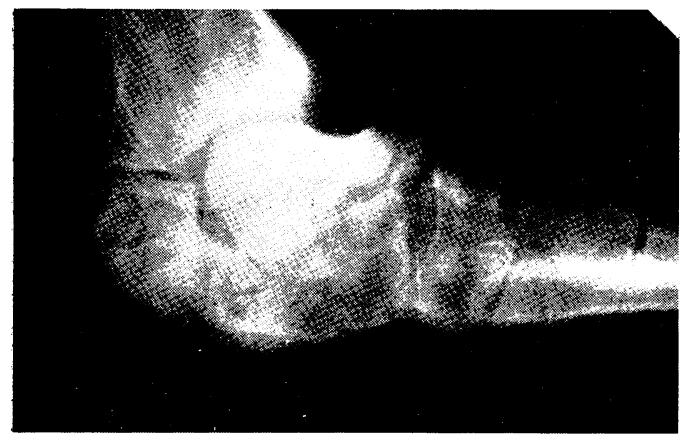

Case 3 Six years ago, he sprained his left ankle, but did ont receive any treatment and then continued to walk.

Fig. 11 Charcot-like changes and pes valgus deformity were noted.

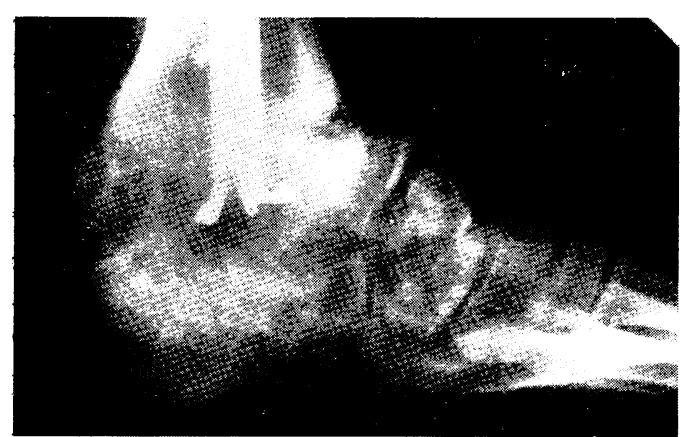

Fig. 12 One year and three months after arthrodesis by $\mathrm{K}-\mathrm{U}$ compression plate.
痛がある。レ線像は変形著明で，足根骨の位置関係が明 らかでないが，破壊は距骨，腫骨が主で，一部遊離体も 認められる。(Fig. 11)

外反足矯正のためと, 軽度の instability 並びに疼痛 があるために，足関節固定術を行なった。足関節内側よ り，K-U Compression Plate にて固定し， 3 カ月後に は骨梁の交通を認め，現在術後 1 年 3 力月であるが，経 過は順調で，よく歩行できる状態である。遊離体並びに 関節切除切片には“らい” 性肉芽腫の存在は認められな かった。(Fig. 12)

附 : 次は増殖性変化を示すまれな型であるが一例にこ の増殖性変化が認められた。

本症例は 3 年前に捻挫してより，足関節内外踝が罙出 した変形をみている。 stability はよく保たれているし， 異常可動性，雑音もないが，500m 程歩くと痛みを訴え る。レ線像は足関節周囲に不規則な増殖像を示し, 脛骨 と腓骨は癒合し，足関節の関節面で硬化像を示して，関 節裂隙は不規則，かつ一部脛骨と癒合しているところも 認める。距骨は変形著明で，踵骨と癒合し，踵骨隆起は 上方にひっぱられた型で舟底状変形を認める。(Fig. 13)

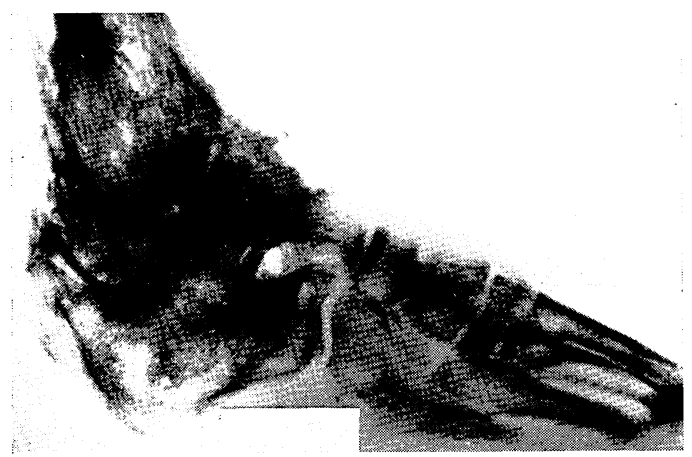

Fig. 13 This only one case with proliferating changes, that are rare in leprosy.

以上足関節を中心とした Charcot 様変化は 2 つの型 がある。

1つは捻挫のくり返しによって起つたものと思われる もので，臨床上 lateral stability が悪く, 起立位で内反 位を示すもので， レ線上距骨の変形と硬化と遊離体を有 する型である。この中初期の捻挫を治療したものと，治 療しなかったものでは, 臨床上, レ線上差異を生じる。

他の 1 つの型は捻挫の時より, 足関節内外踝が突出し た変形を有し, 臨床上 stability は前者に比べれば比較 的よく保たれている。レ線上は距骨の変形著明で, 足関 節面は硬化像を示し，不規則で，Fragment は足関節前 
面に多く見られる型で，捻挫の時に足関節脱臼骨折を経 過し, そのまま歩行し続けた結果, このような像を呈し たと思われる型のものである。

また全体を通じて，足関節の脛骨関節面の破壊が見ら れないのは注目に值することであった。また亜型とし て，1例に増殖性変化を示すものを認めた。

\section{3 . 距骨下関節}

距骨下関節の Charcot 様変化は Tabes の破壊と似 てはいるが，その程度は Tabes のように，無軌道に踵 骨が破壊吸収されて，踵骨の中に距骨がすっぽりはまり 込むまで, 発展しているものは見うけられない。しかし “らい”でも踵骨の後方関節面下の破壊吸収と, その吸 収像の周囲の硬化像として現われる。(Fig. 14) 踵骨の 吸収が進むと，距骨が踵骨の中に落ち込んだ程度のもの は認められ，またその反対に距骨下面の破壊吸収される 場合もある。いずれにしても距骨下関節面の不適合が 起り, 踵骨もしくは距骨に破壊吸収が起ってくるが，踵 骨が吸収される型のものが多く見られ，足関節の方は intact である。

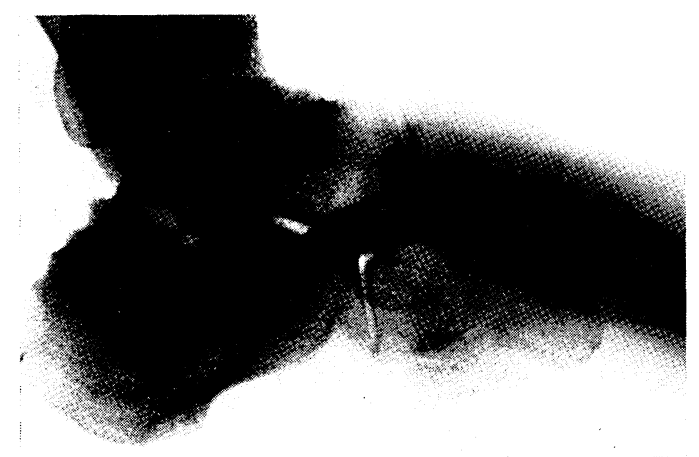

Fig. 14 Charcot-like changes in subtalar joint.

これらの症例は Table 5 に示すように, いずれも誘 因なく腫脹で始まっている。これは足関節が捻挫で始ま るのと大きな違いである。現在は腫脹だけで, 安定性は 比較的よい。腫脹の経過年数が皆短かく $1 \sim 2$ 年である

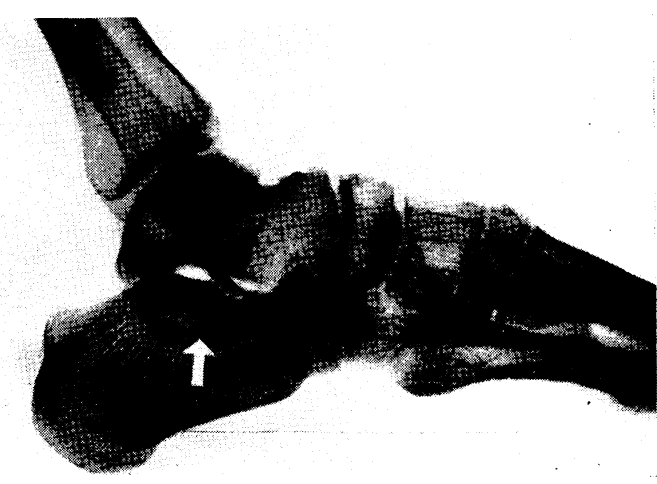

Case 4

Fig. 15 Although he had had his swollen ankle and a mild change of the subtalar joint, that had been overlooked, he continued to walk.

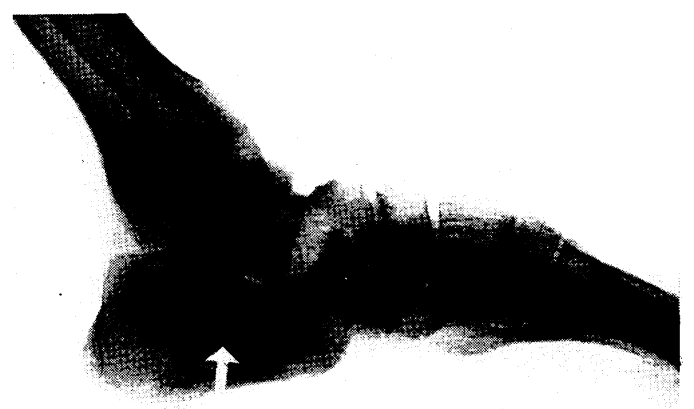

Fig. 16 The roentogenogram three months later revealed that disintegration of the calcaneum had progressed.

After one year, there was no more remarkable change seen.

ので，これらが将来どのように発展もしくは鎮静するか は興味のあるところである。現在のところ，足関節迄破 壊が波及した症例はないが，Harris と Brand は，距骨 下関節の下縁から侵蝕され，距骨はなくなり，完全に足 関節が不安定になるといっている。距骨が完全に吸収さ

Table 5 Subtalar joint

\begin{tabular}{|c|c|c|c|c|c|c|c|c|c|c|c|c|c|}
\hline No. & Name & sex & age & type & $\begin{array}{l}\text { drop } \\
\text { foot }\end{array}$ & cause & $\left|\begin{array}{c}\text { tearm } \\
\text { since onset } \\
\text { (years) }\end{array}\right|$ & $\begin{array}{l}\text { treatment } \\
\text { at onset }\end{array}$ & swelling & deformity & stability & $\begin{array}{c}\text { abnormal } \\
\text { mobility }\end{array}$ & pain \\
\hline 1 & T.N. & $\mathrm{F}$ & 61 & $\mathrm{~T}$ & - & spontaneous & 1 & none & H & - & good & - & - \\
\hline 2 & N.K. & $\mathrm{M}$ & 47 & $\mathrm{~L}$ & + & "I & 1 & "I & $H$ & - & "I & - & - \\
\hline 3 & T.U. & M & 42 & $\mathrm{~L}$ & - & "I & 2 & $\begin{array}{l}\text { plaster } \\
\text { cast }\end{array}$ & ii & - & "1 & - & - \\
\hline 4 & T. I . & $\mathrm{M}$ & 42 & $\mathrm{~L}$ & + & "I & 4 & "I & it & - & $\prime \prime$ & + & + \\
\hline
\end{tabular}


れてしまうものは, 距骨の crack fracture 後, それを 知らずに歩き続けることによって起って来ると思われる が，このような症例の経験はない。反対に距骨の crack fracture を固定により, 変形治癒をはかり, 距骨の破壊 吸収からすくいえたと思われる症例の経験はある。

症例 4, 61歳古, L型, らい発病経過29年, 昭和42年 12月, 誘因なく左足関節が腫脹してきたが，その時のレ 線像で, 踵骨後方関節面下の破壊は見逃がされて, その まま歩行している。腫脹が続くので, 3 力月後受診, 踵 骨の破壊は進み, 距骨が踵骨の中に沈んだようになって いた。現在装具を与えて, 経過をみているが，1年後の 現在破壞吸収は進んでいない。(Fig. 15，16)

参考症例, 51歳今, L型, らい発病経過 25 年, 昭和 42 年 1 月に誘因なく, 左足関節に腫脹, ENL 著明, 菌指 数 3.3 である。レ線上では踵骨に蜂窩状の吸収像を認め たので, ギプス固定を施し， 3 力月後には硬化像を示し 始め, 6 力月後には骨梁もきれいに修復されている。こ の蜂窩状吸収像は, 諸家が phalanx に多くみられると 云う Leprous Osteomyelitisの像と一致したレ線像で, この時に免荷を䓌たり, 荷重歩行を続けていれば, 破壊 は進んで, Charcot 様変化に発壻していったかも知れな い。(Fig. 17, 18)

この参考症例から, 距骨下関節の Charcot 様変化を Leprous Origin と考えたいが, 症例 4 の初期像とは全 然違つたレ線像を呈している。固定によく反応して, き

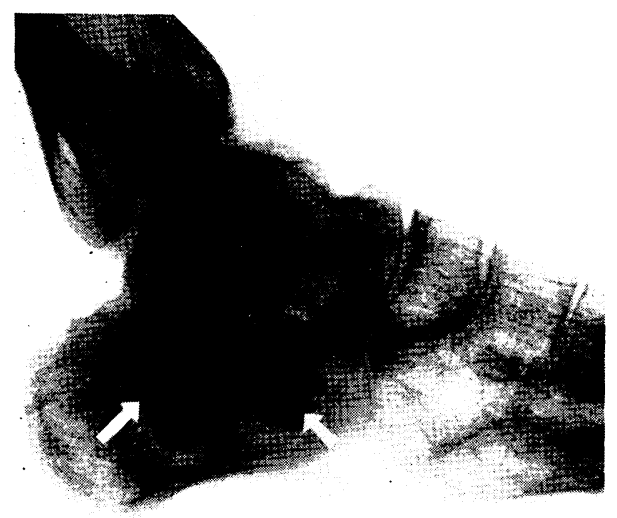

Leprous osteomyelitis of the calcaneum-reference case

Fig. 17 His left ankle has been swollen without any cause and ENL has developed. The bacterial index is 3.3 . The honeycombing translucency is noted in the calcaneum.

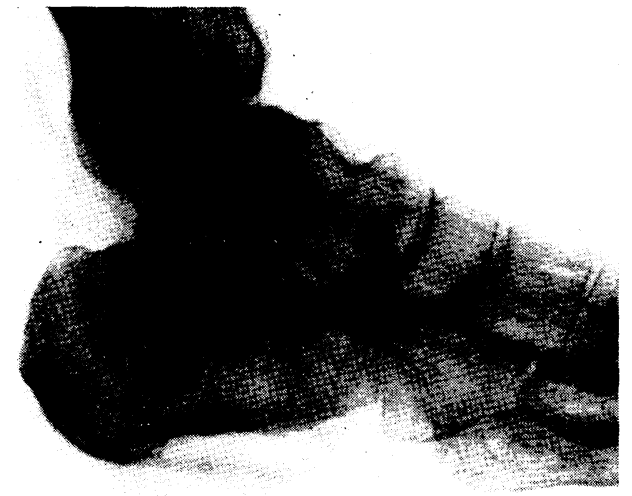

Fig. 18 Satisfactory repairs were obtained after six months.

れいに修復されたことは, Leprous Osteomyelitis とは 思うが，これが Charcot 様関節に発展するかは疑問で ある。

\section{Chopart 関節}

らいの Chopart 関節の Charcot 様変化は Diabetes や, Tabes に見られる変化と何ら変ったところはない。 Paterson は Talus and Navicular Neuropathy と呼 び,この Chopart 関節だけに Neuropathy を限定して いる。また Haaris と Brand もこの部の変化を Common and Consistent pattern といっている。この Cho part 関節の Charcot 様変化は Navicular の破壞を中 心として起る。Navicular は破壞し, Fragmentation を起し，上方にはみだしたようになり，その結果距骨の 頭部や立方骨にも破壊は及ぶ。(Fig. 19)

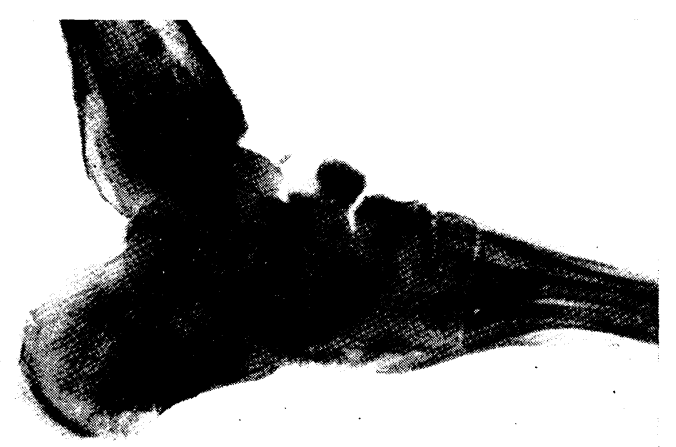

Fig. 19 Charcot-like changes in chopart joint.

集めえた Chopart 関節の Charcot 様変化は 8 例で, Table 6 に示す。これらの臨床上の特長は, 表に示すよ らにまずL型に多い。8例中 7 例が L 型で，T型は 1 例のみである。次に誘因と思われるものがなく，捻挫な 
Table 6 Chopart joint

\begin{tabular}{|c|c|c|c|c|c|c|c|c|c|c|c|c|c|}
\hline No. & name & sex & age & type & $\begin{array}{l}\text { drop } \\
\text { foot }\end{array}$ & cause & $\begin{array}{c}\text { tearm } \\
\text { since onset } \\
\text { (years) }\end{array}$ & $\begin{array}{l}\text { treatment } \\
\text { at onset }\end{array}$ & swelling & deformity & stability & $\begin{array}{l}\text { abnormal } \\
\text { mobility }\end{array}$ & pain \\
\hline 1 & T.A. & M & 35 & $\mathrm{~L}$ & + & $\begin{array}{l}\text { sponta- } \\
\text { neous }\end{array}$ & 1.5 & none & $H$ & planus & goop & - & - \\
\hline 2 & M.E. & M & 57 & $\mathrm{~L}$ & - & " & 10 & " & - & planovalgus & "I & - & - \\
\hline 3 & S.A. & M & 47 & $\mathrm{~L}$ & - & "I & 4 & "I & + & $\begin{array}{l}\text { navicular } \\
\text { projection }\end{array}$ & "I & - & + \\
\hline 4 & T.H. & $\mathrm{F}$ & 68 & $\mathrm{~L}$ & - & "I & 3 & $\prime \prime$ & - & planus & " & - & - \\
\hline 5 & J.O. & $\mathrm{M}$ & 42 & $\mathrm{~L}$ & + & " & 5 & " & - & planovalgus & $\prime \prime$ & - & - \\
\hline 6 & T.A. & $\mathrm{M}$ & 66 & $\mathrm{~L}$ & - & sprain & 3 & $\begin{array}{l}\text { plaster } \\
\text { cast }\end{array}$ & - & $\begin{array}{l}\text { navicular } \\
\text { projection }\end{array}$ & " & - & - \\
\hline 7 & T.A. & $\mathrm{F}$ & 45 & $\mathrm{~L}$ & - & $\begin{array}{l}\text { sponta- } \\
\text { neous }\end{array}$ & 7 & none & - & planus & $\prime \prime$ & - & - \\
\hline 8 & M. T. & $\mathrm{F}$ & 50 & $\mathrm{~T}$ & + & " & 2 & "I & H & planovalgus & " & + & + \\
\hline
\end{tabular}

ぞの外傷の既往もない。足関節では捻挫もしくは捻挫の くり返しによって起ってくるものが，大多数であったの に比較して,この Chopart 関節では捻挫は 1 例のみで, 他は誘因と思われるものがない。

誘因なく腫脹, 熱感で始まっている。この腫脹熱感で あるが, Harris と Brand は熱感が最も価值あるもの で，足根骨の破壊の early sign であり，足部が正常 で，患者が何ら訴えなくても，局所熱感のある場合は， レ線撮影をしているとのことである。しかし“らい”患 者においては，熱感はわからず，我々が診察する場合 は early sign であるかも知れないが，“らい”患者 の場合, 局所熱感より, 腫脹を強調したい。事実訴えて くる場合は，腫脹を訴えてくるのであるから，知覚の ない“らい”患者に局所熱感に注意を払うよう警告し てもはじまらない。少なくとも，足根骨の病的骨折と Leprous osteomyelitis は, 誘因なく腫脹熱感ではじま るので，早期に治療を開始すれば，治癒しうることはで きる。同様に Chopart 関節の Charcot 様変化も誘因な く腫脹熱感ではじまる。経過を観察しえた 1 例では, こ の時期に治療を開始したが, Charcot 椂変化を阻止する ことができなかったので, Harris と Brand がいうごと く，正常な腫脹のない足でも，熱感がある時期に Charcot 様変化を check できて, control することができ れば, 熱感は earliest warning とされるであろう。と もあれ，誘因なく腫脹熱感ではじまる。この腫脹は 6 カ 月から 1 年間ぐらいで消褪し, 多くは外反扁平の変形を のこしていて, stability は良好のまま経過している。 従って異常可動性, 雑音などもなく, 歩行時の疼痛もな く，歩行能力は良好なものが多い。
参考症例，42歳含，L型，らい発病経過10年, 昭和39年 1 月, 誘因なく両足関節に熱感を伴つて腫脹した。両足 ともに腫脹は中程度にあり, 腫脹の中心は Chopart 関 節である。皮膚の “らい”性変化は ENL の出現をみ

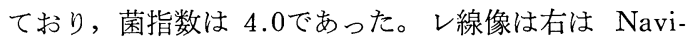
cular が中心で, 高度に破壊圧壊されて, 第 1 Köhler 氏病を思わせる。立方骨にも蜂窩状の吸収像を認める。 左は Cuneiform を中心として破壊され, 立方骨の一部 と諸骨の前方関節面下にも破壊吸収像を認める。1 力月 のギプス固定のみで， 3 カ月後には硬化像を示しはじ め, 6 力月後には破壊吸収のあったところに, recalcify が起こり, 修復されている。 3 年後のレ線では多少の変 形をのこしているが，きれいに修復されている。このよ うに突然破壊が現われ，固定により recalcify され，だ んだんと修復されたことはそれが炎症であったことの証 左であると思われる。しかし Biopsy をしていないの で，確定的なことはいえないが，Leprous osteomyelitis であったと思われる。(Fig. 20，21，22)

1931年 Edward and Wayson³)をはしめとして，いま まで諸家が報告している Leprous osteomyelitis は手足 の phalanx に多くみられている。足根骨に Leprous Osteomyelitis が起ったと発表されているのは，著者が 調べた範囲では1950年 Erickson and Mayoral12 の論文 だけである。彼らは Talus neck and head の破壊吸収 された 2 例を経験し， 1 例は固定で修復されたことによ りここれは Leprous origin であり, 他の 1 例は体重負 荷が早かったためか, Charcot's joint に発展したと述 べている。それで Leprous origin と考えられた破壊吸 収は, 治療を適切にしないと Charcot's joint に発展す 


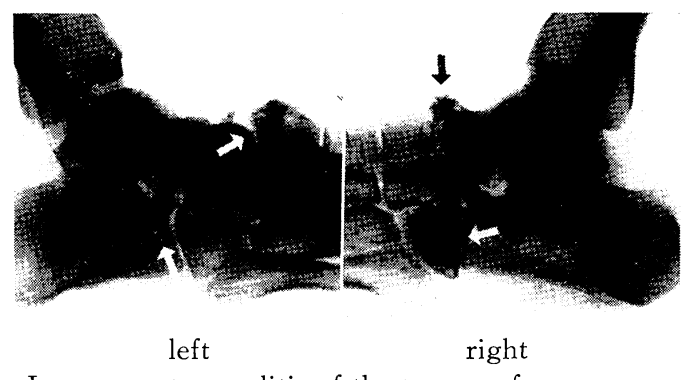

Leprous osteomyelitis of the tarsus-reference case.

Fig. 20 Bilateral foot were suddenly swollen without any cause in January, 1964. The roentogenogram shows tne destruction of right nabicular bone and honeycomb like changes of cuboid bone. The destruction of left cuneiform, cuboid bone and anterior portion of calcaneum are noted.

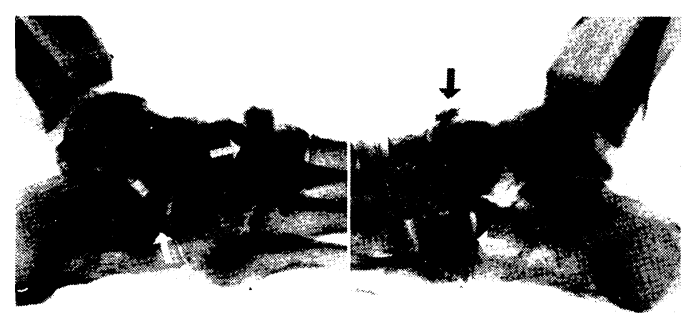

Fsg. 21 The radiograph in July, 1964 shows recalcification.

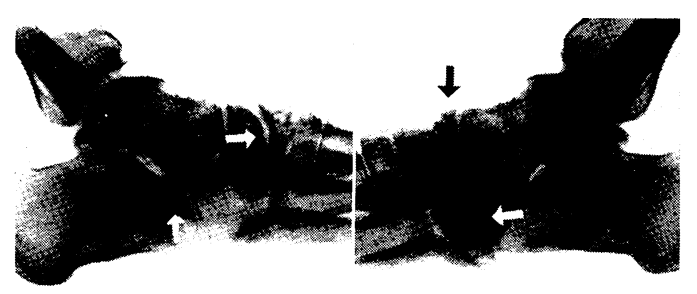

Fig. 22 Radiograph taken in July, 1967. Clear repair of tarsus is obtained, though a mild deformity is present.

る starting pooin になる可能性があるとしている。

1961年 Patesron は talo-navicular Collapse は後脛 骨筋腱移行術またはギプス固定後の早期荷重的の minor trauma 等で起るであろうとしているが，掲載されてい るレ線写真の Talus の collapse と踵骨前方関節面下の 破壊は, 著者の参考症例のレ線写真と全く同一のように よく似ている。またその破壊もよく修復されている。

1966年 Harris と Brand は Chopart 関節の破壊は, navicular fracture が起り, その後歩き続けるために骨
折面は磨滅され，骨は fragment となり，完全に破壞 されて行くと述べているが，そこに揭載されているレ線 写真は Navicular の破壊と脛骨の前方関節面下の破壊 があって著者の参考症例と非常によく似ている。このよ うに

1） 3 者が掲載しているレ線写真の破壊と著者の参考 症例とはよく似ていること。

2）固定によりいずれもよく修復されていること。

3） L型に多く発症していること。

4）足関節と違って誘因なく発症すること。

5）熱感を伴った腫脹で始まり，いずれも鎮静してい ること。

6) Erickson と Mayoral の Leprous Origin の説が あること。

上記の理由で, Chopart 関節に起る Charcot 様変化 は，初期には Leprous osteomyelitisによって始まるの ではなからうかと推論し, 昭和 43 年 4 月第41回日本癩学 会総会にその旨を発表した。しかし次の症例は全く違っ た経過を示した。

症例 5,35 歳今, L型, らい発病経過 20 年, 昭和 42 年 8 月, 誘因なく左足関節腫脹, $\mathrm{ENL}$ はなく, 菌指数 1.0 であった。レ線上は Navicular の上方に小さな fragment があるのみであった。しかるに 1 力月後の 昭和 42 年 9 月には Navicular の破壊が明らかに現われていた ので，早急に固定免荷装具を作製した。しかし破壊はだ んだんと強くなり，3 カ月後の昭和 42 年 11 月には典型的 な Charcot 様変化を示している。このように全く control は出来ず，急速に破壊してしまっている事は，前の 参考症例とは全く違った経過を示し，これが Charcot 様変化の経過と考えられる。(Fig. 23，24，25)

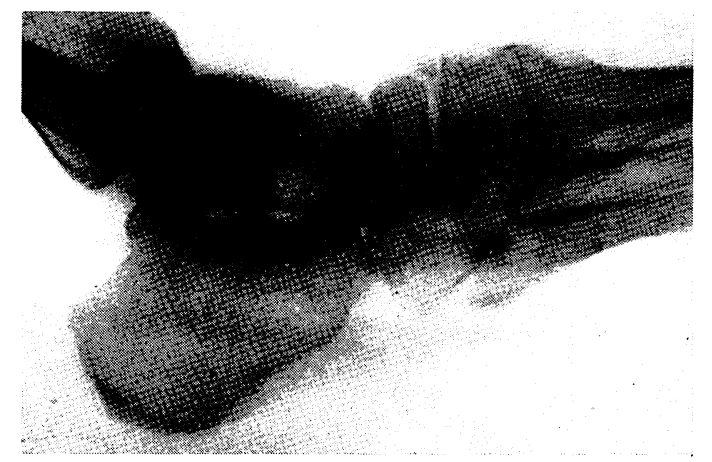

Case 4

Fig. 23 His left ankle was swollen without any cause in August 1967, when the fragmentation of navicular bone was only noted. 


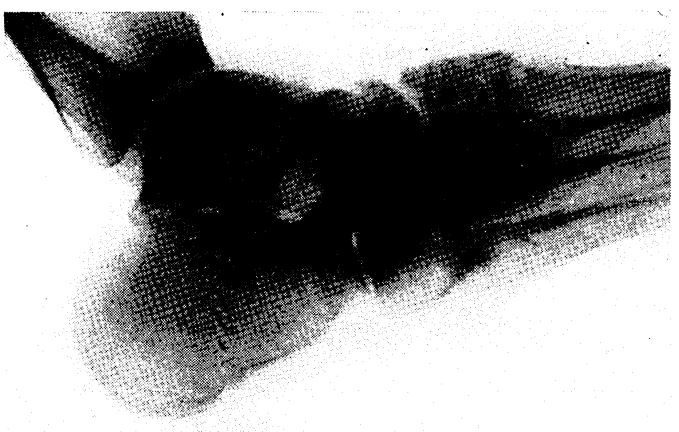

Fig. 24 One month later, the disintegration of navicular bone was seen.

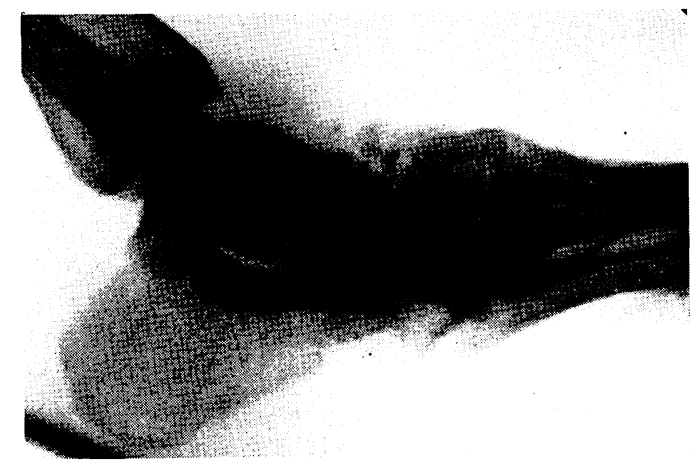

Fig. 25 Three months later, Charcot-like change became more typical, though the affected foot had been immobilized in brace.

It is difficult to control rapid progress of the condition.

参考症例は破壊が先に 突然現われて，ギプス 固定 1 カ月と短かいのにかかわらず，その破壊がだんだんと recalcify されて修復されて行った過程と, 症例 5 は, 固定装具を与えたにもかかわらず，だんだんと破壊が著 明になって行っている過程とは誠に対称的であり, 前者 は Leprous osteomyelitis であり, 後者は Charcot 様 変化であると考えられる。

Erickson と Mayoral も経験した Leprous origin の一連の修復された過程は再生傾向が早く, 治癒は早く
起ることを指摘しており，また Harris と Brand は骨 損傷を認めたならば，強固な固定を行なうべきで，骨の 癒合はギプス固定で，長くはかかるが，起るであろう。 しかし一旦破壞が始まると，その急激な破壊を停止ささ ることは困難であると結論でのべている。

5 Lisfranc 関節

Lisfranc 関節の Charcot 様変化は Cuneiform の破 壊である。Fig. 26 が示すように Cuneiform は破壊変 形が著しい。Cuboid も破壊変形を示すものが多い。 Chopart 関節にみられるような fragmentation を起し， 硬化像を示しているのはない。従つて現在の臨床症状は いずれも異常可動性はなく，安定した関節となってい る。ただ外観上，外反扁平の変形を有するのみで，歩行 痛もなく，歩行能力もよい。この型のものは 4 例見るこ とができたが，経過を follow-up しえた症例は 1 例も ない。これら 4 例は15年〜20年前に捻挫し，その後外反 扁平の変形が起ってきているというので，その時 Cuneiform の骨折が先行してできたものであるかも知れな いが，Cuneiform が吸収されるようなことは， anesthetic foot であるのに関係するものであろうと考える。 (Fig. 26)

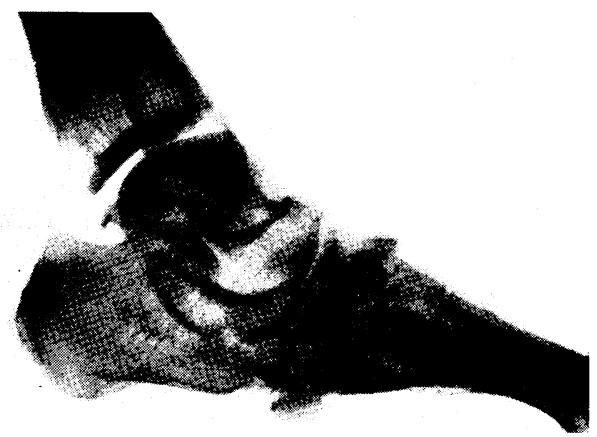

Fig. 26 Disintegration in the Lisfrance's joint.

$$
\text { 考案 }
$$

“らい”のCharcot's joint の報告は少なく，1961年 Paterson は，“らい”の骨変化の中で Charcot's joint

Table 7 Lisfranc joint

\begin{tabular}{c|c|c|c|c|c|c|c|c|c|c|c|c|c}
\hline \hline No. & name & sex & age type & $\begin{array}{c}\text { drop } \\
\text { foot }\end{array}$ & cause & $\begin{array}{c}\text { tearm } \\
\text { since onset } \\
\text { (years) }\end{array}$ & $\begin{array}{c}\text { treatment } \\
\text { at onset }\end{array}$ & swelling & deformity & stability & $\begin{array}{c}\text { abnormal } \\
\text { mobility }\end{array}$ \\
\hline 1 & H.A. A. & F & 46 & L & - & sprain & 15 & none & - & planovalgus & good & - \\
2 & F.N. & F & 53 & L & - & fall & 20 & $\prime \prime$ & - & $\prime \prime$ & $\prime \prime$ & - \\
3 & Y.T. & M & 61 & L & + & sprain & 20 & $\prime \prime$ & - & $\prime \prime$ & $\prime \prime$ & - \\
4 & K.O. & F & 61 & L & + & $\prime \prime$ & 15 & $\prime \prime$ & - & $\prime \prime$ & $\prime \prime$ & - \\
\hline
\end{tabular}


を論じているものと，1966年 Harris と Brand がこの 問題をとりあっかった唯一の本格的論文があるに過ぎな い。

まず“らい”の足関節においての Charcot 様関節変 化を考察するに，Paterson は足関節における Charcot's joint は neglected trauma の結果であろうといっ ている。すなわち患者は関節附近に小さな骨折をうける が, 痛みがないために, その状態を軽視し, 大きな関節 血腫をつくり, 関節腔は拡大し, 関節包は驰緩して, 亜 脱臼, 脱臼を起して, Charcot's joint に移行するとし ている。著者もこの意見に賛成である。教室の鬼塚 ${ }^{5)}$ 3 例の Charcot's joint を経験し, いずれも足関節では くり返しおこる捻挫によって破壊が起ってくると述べて いる。一方 Harris と Brand は Tabes は通常足関節 に起るに比較して, “らい”では足関節に起ることはま れであるのは興味があるとしている。事実足関節の脛骨 関節面の破壊が見られたものは 1 例もない。この事は注 目に值する事柄である。しかし著者の観察しえた足関節 の Charcot 様変化は19例と多く, Paterson, 鬼塚がい っているように, 捻挫のくり返しで起ってくる一連の変 化がある。それはレ線上距骨の変形, 硬化と関節内の遊 離体に特長づけられている。また捻挫のくり返しの経過 が長くなると, その変化は, 足根骨全体の破壊となって 現われてくる。これらの足関節の変化は, 他の疾患の Charcot's joint と少し趣きを異にしている。これは足 関節の脛骨関節面が破壊されないこと, 増殖性変化を示 すことはまれであること，そしてこれらの変化を起す経 過が長いことなどにより, レ線上, 上記のような異った 像を呈していることがいえると思う。それでこれらを “らい”の Charcot 様関節変化と呼びたい。

一方足関節以外の距骨下関節と Chopart 関節の Charcot 様変化は Tabes や Diabetes に見られるのと同様 な Charcot's joint の変化を示す。ただその程度が著し くなく, 無軌道ではない点が違っている。そして他の疾 患のCharcot's joint と同様に誘因なく腫脹ではじま る。起り方, レ線像は他の疾患の Charcot's joint に似 ているが，破壊が無軌道でないためか，いずれも異常可 動性は少なく, 従って stability は良好であることは甚 だ異なるところである。

誘因なく腫脹する中にあって, 始めにレ線上破壊が現 われて，固定により修復しらるものがあるが，これは Leprous osteomyelitis であろうと考える。1931年 Edward and Wayson, 1932年, Murdock and Hutler, 1933年林, 1948年, Erickson 1961年 Paterson, 1963 Job,
1964年 Brand 等が報告した Leprous osteomyelitis は 手足の phalanx に多く見られ, 多発し, その破壊吸収 と修復過程は，著者が示した参考症例と全く同一であ り，足根骨にも Leprous osteomyelitis は起りうると考 えられる。この Leprous osteomyelitis の初期破壊時 に体重負荷を行なえば，破壊がだんだんと進み，いわゆ る Charcot 様関節変化を起すかも知れないと考えた。 また，1967年村上 ${ }^{6)}$ は Charcot 様変化にも 100\%に “ら い”性肉芽組織が見られるといっている。このようなこ とから“らい”患者で, 足関節以外の距骨下関節, Chopart 関節にくる Charcot 様変化は, Leprous origin ではないかとして癩学会に発表した。しかしその後 Control のむずかしい典型的な Charcot 様関節を経験 したこと，2，3の手術時にとった組織の中からは, “らい”性肉芽腫なるものは発見できなかったこと, Leprous osteomyelitis は固定により修復が意外と早く 起る一方, Charcot 様関節変化は固定しても急速に関節 変化が発展することなどからして，一連の Charcot 様 関節変化は Leprous Origin と考えていたのを訂正せざ るを得ない。しからば, それが初期には Leprous osteomyelitis でないとしたら, 何であろうか。いままで経 験した例では, 足部に誘因なく腫脹で始まるものは, Leprous osteomyelitis か, 病的骨折か, Charcot 様関 節変化か, この三者であるので, 残りの病的骨折が最初 の変化であろうか。

Charcot's joint で外傷が重要な役割を果すことは一 般に考えられている事柄である。

1966年 Eichenholtz ${ }^{73}$ は, 最近の報告では Charcot 関 節の Pathogenesis に関しては外傷が最初の因子である という概念が支持されていると述べている。

1966年, Harris と Brand は“らい”患者の足関節 や, Chopart 関節の破壊は, それぞれ距骨や，舟状骨 の骨折の後に歩き続けることにより起ってくるとしてい る。

1967年, Johnson ${ }^{8}$ は118例の Charcot's joint を観察 し, 典型的な神経病性関節症では, 骨折が初めの病変で あったという確実な証明はないが，多くの Charcot's joint では初めの病変は認められない stress fracture で あろう。そして骨折が関節変化を開始させ, 進行して行 く重要なものであると結論している。

1968年成田 ${ }^{9}$ は，“らい”患者の足穿孔症の治療のた めに, ギプス包帯をし, 病棟に入れて安静を守らせた 60 余例中からギプスシャーレにして数日内に 3 例に Lisfranc 関節の神経病性関節症を認めている。そしてこの 
事は病的骨折後に 起ったものではないかと推論してい る。

著者100は先きに“らい”患者の距骨病的骨折の 2 例を 経験し，固定により 変形は残したが，治㾣した 症例を 発表した。この距骨病的骨折を知らずに歩き 続けると Charcot's joint に発展していったかも知れない。しか しその病的骨折より Charcot's joint に移行したという ことを明らかに示した人はいない。著者の考えでは， Charcot 様関節変化は初めから Charcot 様関節になる ものであろうと思われる。なぜなら，誘因なく腫脹で始 まる3者の中で, Leprous osteomyelitis と病的骨折は 固定でよく反応し，修復しうるからである。

\section{結ひび}

1. らい患者の Charcot 様関節変化は，足部の関節 に多くみられ，その他の関節にはほとんど見られない。

2. 足関節の Charcot 様関節変化は 2 つの Type が あり, 1 つは捻挫のくり返しで発生し, 臨床上 lateral stability が悪く, 内反位を呈し, レ線上は距骨の変化が 中心で, 距骨の変形硬化と遊離体を認める。他の 1 つは 足関節脱臼骨折の後, 歩き続ける為に起ったものと思わ れるもので, 臨床上は足関節内外踝の突出した変形を有 し, stability は比較的良好で, レ線上の変化は, 前者 とほぼ同じであるが，その変化はより高度である。

3. 距骨下関節の Charcot 様関節変化は誘因なく腫 脹で始まる。踵骨の破壊で, その変化は他の Charcot's joint に比較して, 無軌道な破壊でなく, 従つて stab- ility は良好のまま経過する。

4. Chopart 関節の Charcot 様関節変化は, 誘因な く腫脹で始まり，レ線上は舟状骨の破壊が中心で，他の Charcot's joint と全く同様である。

5. Lisfranc 関節では, 楔状骨の破壊であり捻挫で始 まり, 外反扁平の変形を残すのみである。

ご指導・ご校閱いただいた恩師玉井達二教授に深謝す る。

\section{文献}

1) Paterson, D. E. : Bone changes in leprosy. Internat. J. Leprosy, 29, 393 (1961).

2) Harris,- J. R. \& Brand, P. W. : Patterns of disintegration of the tarsus in the anesthetic foot. J. B. J. S., 48-B, 4(1966).

3) Edward \& Wayson: The bone and joint changes of leprosy, Radiology, 17, 930 (1931).

4) Erickson \& Mayaral: Unusual lesion of talus occuring in leprosy, Radiology, 54, 357 (1950).

5）鬼塚敞：癩の手足骨レ線像変化に関する知見補 遺, 熊本医学会雑誌別刷, 39, 464(1965).

6）村上雄一：ライ患者足部骨変化の X線像および 病理組織学的研究, 熊本医学会雑誌別刷, 41 (5), 437 (1967).

7) Eichenholtz: Charcot Joints, Springfield, Illinosis, Charles C Thomas, (1966).

8) Johnson, J. T. H. : Neuropathic Fractures and Joint Injuries. J. B. J. S., 49-A, 1(1967).

9）成田稔：らいに括ける神経病性関節症，レプラ, 37, 169 (1968).

10）松田秀雄他：らい患者にみられた距骨病的骨折 の 2 例, 医療, 23(1969) 掲載予定. 